\title{
HUBUNGAN PENGETAHUAN DAN SIKAP MAHASISWA UNIVERSITAS BHAKTI KENCANA GARUT DENGAN PROMOSI KESEHATAN DIMASA PANDEMIC COVID-19
}

\author{
Ridwan Riadul Jinan ${ }^{1 *}$, Winasari Dewi ${ }^{2}$ \\ Universitas Bhakti Kencana Garut ${ }^{1,2}$ \\ ridwan.riaduljinan@bku.ac.id ${ }^{l^{*}}$
}

\begin{abstract}
ABSTRAK
Mahasiswa dituntut untuk menjadi promotor dibidang kesehatan khususnya dalam rangka pencegahan dan penanggulangan COVID-19. Pada penelitian ini akan di ukur pengetahuan dan sikap mahasiswa UBK Garut dan di teliti hubungannya dengan perilaku mahasiswa tersebut apakah dia melakukan promosi kesehatan khususnya tentang COVID-19 ini atau tidak, Desain penelitian korelasional dengan Crosssectional yaitu hubungan pengetahuan dengan perilaku dan sikap dengan perilaku. Penelitian ini bertujuan Untuk Mengetahui hubungan pengetahuan dan sikap mahasiswa Universitas Bhakti Kencana Garut dengan promosi kesehatan dimasa pandemic covid-19. Penelitian ini bersifat deskriptif analitik dengan pendekatan kuantitatif. Jumlah responden dalam penelitian ini 234 orang dengan teknik pengambilan sampel yaitu total sampel. Penyajian data dilakukan dengan menggunakan tabel distribusi frekuensi. Hasil penelitian menunjukkan bahwa pengetahuan responden tergolong baik (94\%), sikap negatif $(55,6 \%)$, dan perilaku terbesar $(64,5 \%)$ yaitu melaksanakan promosi kesehatan. Dari analisa bivariat tidak ada hubungan pengetahuan tentang promosi kesehatan terhadap perilaku promosi kesehatan mahasiswa pada saat pandemi $(\mathrm{p}=0,241)$, dan tidak ada hubungan sikap tentang tentang promosi kesehatan terhadap perilaku promosi kesehatan mahasiswa pada saat pandemi $(\mathrm{p}=0,0,562)$. Untuk Mahasiswa disarankan lebih giat membantu program pemerintah khususnya melakukan promosi kesehatan pada saat pandemi covid 19.
\end{abstract}

Kata kunci : Pengetahuan, sikap, perilaku, promosi kesehatan

\section{ABSTRACT}

Students are required to be promoters in the health sector, especially in the context of preventing and overcoming COVID-19. In this study, the knowledge and attitudes of UBK Garut students will be measured and their relationship with the student's behavior will be measured whether he or she does health promotion especially about COVID-19 or not. The research design is correlational with cross-sectional, namely the relationship between knowledge and behavior and attitudes with behavior. This study aims to determine the relationship between knowledge and attitudes of Bhakti Kencana University students in Garut with health promotion during the COVID-19 pandemic. This research is descriptive-analytic with a quantitative approach. The number of respondents in this study is 234 people with a sampling technique that is the total sample. Data presentation is done by using a frequency distribution table. The results 
showed that the respondents' knowledge was classified as good (94\%), negative attitude $(55.6 \%)$, and the largest behavior (64.5\%) was implementing health promotion. From the bivariate analysis, there was no relationship between knowledge about health promotion and student health promotion behavior during a pandemic $(p=0,241)$, and there was no relationship between attitudes about health promotion and student health promotion behavior during a pandemic $(p=0,0,562)$. Students are advised to be more active in helping government programs, especially in carrying out health promotion during the COVID-19 pandemic.

\section{Keywords: Knowledge, attitude, behavior, health promotion}

\section{PENDAHULUAN}

Pandemi COVID-19 muncul ketika virus ini diketahui menyebar dari orang ke orang dalam waktu singkat dan dengan gejala seperti demam tinggi, batuk, sesak, tidak nafsu makan dan lemas. COVID-19 pertama kali dilaporkan di Wuhan, Hubei, Cina pada Desember 2019, dan pada 11 Maret 2020 Organisasi Kesehatan Dunia (WHO) menyatakan bahwa COVID-19 telah menjadi penyakit pandemi di seluruh dunia (World Health Organization, 2020).

Wabah COVID-19 ditetapkan sebagai pandemik global oleh WHO pada 11 Maret 2020, dengan peningkatan 13 kali lipat dalam jumlah kasus yang dilaporkan di luar China, lebih dari beberapa minggu.1 Ini telah mempengaruhi lebih dari 2,3 juta orang di 185 negara di dunia. Dari total beban global, sedikit di atas 120 ribu kasus yang dikonfirmasi dan 5784 kematian dilaporkan di EMRO pada 18 April 2020. KSA, dengan 7142 kasus dan 87 kematian, adalah yang ketiga negara di kawasan yang akan terpengaruh oleh novel coronavirus atau SARS-CoV-2 (sindrom pernafasan akut yang parah) CoV-2). Angka fatalitas kasus (CFR) secara keseluruhan di antara semua negara adalah $6,8 \%$, tetapi tertinggi di Italia pada $13,1 \%$. Pandemi COVID19 dapat menjadi pandemi kategori 3,tergantung pada nomor reproduksinya (R0) dan keseluruhan rasio fatalitasnya jauh (Mansuri, Zalat, Khan, Alsaedi, \& Ibrahim, 2020). Kasus COVID-19 yang dilaporkan ditemukan di 203 negara di seluruh dunia pada awal April 2020, dengan total 937.976 kasus yang dikonfirmasi dan 47.279 kematian. Pada Bulan April 2020, Indonesia menunjukkan sejumlah besar kasus dan kematian yang dikonfirmasi dalam wabah COVID19, dan diperlukan strategi pencegahan untuk penyebarluasan penyakit yang lebih parah (World Health Organization, 2020).

Peningkatan jumlah kasus COVID-19 terjadi dalam waktu yang sangat cepat sehingga membutuhkan penanganan segera. Virus corona dapat dengan mudah menyebar dan menginfeksi siapapun tanpa pandang usia. Upaya pemutusan rantai penyebaran COVID-19 memerlukan pemahaman dan pengetahuan yang baik dari seluruh elemen termasuk masyarakat. Pengetahuan tentang 
penyakit COVID-19 merupakan hal yang sangat penting agar tidak menimbulkan peningkatan jumlah kasus penyakit COVID-19. Pengetahuan pasien COVID-19 dapat diartikan sebagai hasil tahu dari pasien mengenai penyakitnya, memahami penyakitnya, cara pencegahan, pengobatan dan komplikasinya (Mona, 2020).

Tindakan protocol kesehatan yang ditetapkan oleh WHO dan Kementerian Kesehatan RI tidak akan berjalan sebelum masyarakat dibekali dengan pengetahuan, sikap dan keterampilan yang baik dalam pelaksanaannya. Diperlukan adanya sosialisasi dan upaya-upaya promosi kesehatan yang gencar sehingga terdapat perubahan pada kognitif, afektif dan psikomotor masyarakat dalam pencegahan COVID-19. Penularan virus Corona (SARSCov2) di tubuh manusia menimbulkan gejala penyakit pneumonia dan gejala serupa sakit flu pada umumnya. Gejala tersebut di antaranya batuk, demam, letih, sesak napas, dan tidak nafsu makan (Kemenkes, 2020). Namun berbeda dengan influenza, virus corona dapat berkembang dengan cepat hingga mengakibatkan infeksi lebih parah dan gagal organ serta kematian (Morfi, 2020). Kondisi darurat ini terutama terjadi pada pasien dengan masalah kesehatan sebelumnya (Mona, 2020). Inilah yang menyebabkan COVID-19 sangat berbahaya dan dapat menyebabkan kematian.

Mahasiswa dituntut untuk menjadi promotor dibidang kesehatan khususnya dalam rangka pencegahan dan penanggulangan COVID-19 ini dikarenakan dengan latar belakang pendidikannya dapat lebih bisa menyampaikan informasi yang benar dalam rangka penanganan COVID-19 ini. Oleh sebab itu perlu di teliti pengaruh pengetahuan dan sikap mahasiswa universitas bhakti kencana garut terhadap promosi kesehatan dimasa pandemic covid-19.

\section{METODE PENELITIAN}

Penelitian menggunakan metode analisis deskriptif kuantitatif. Populasi pada penelitian ini adalah Mahasiswa universitas Bhaki Kencana Garut sebanyak 250 orang total sampling untuk 3 angkatan. Uji Validitas dilaksanakan di Uniersitas Cendikia Abditama dengan jumlah 30 orang Mahasiswa DIII Keperawatan. Data dikumpulkan melalui kuesioner online dengan menggunakan google form dan di sebrkan di grup Whatsapp kelas setiap angkatan. Kuisioner ini, menggunakan pertanyaan tertutup dan pilihan ganda,. Variabel penelitian ini adalah pengetahuan, sikap, dan perilaku, dan untuk setiap variabel ada 10 item yang terhubung dengan menggunakan protokol new normal sebagai salah satu strategi pengendalian pandemi. Pengetahuan diukur dengan apakah responden dapat mengidentifikasi penyebab penyakit dan penularan, gejala umum, risiko dan pencegahan COVID-19. Sikap diukur sesuai dengan kesadaran akan jarak sosial di tempat kerja dan ibadah, serta belajar dari rumah. Perilaku terkait dengan melakukan kegiatan promosi 
kesehatan terhadap masyarakat yang berisi item terkait pencegahan COVID-19.

Pengukuran pengetahuan dan perilaku menggunakan skala Guttman, dan skala Likert digunakan untuk pengukuran sikap. Desain penelitian korelasional dengan Crosssectional yaitu hubungan pengetahuan dengan perilaku dan sikap dengan perilaku. Data dianalisis dengan analisis deskriptif dengan menghitung distribusi frekuensi dan persentase. Penelitian ini mengedapankan prinsip etik autonomy, beneficence, justice, nonmaleficence, veracity, fidelity, confidentiality dan accountability.

\section{HASIL PENELITIAN}

\section{Karakteristik Responden}

Tabel 1

Tingkatan semester Responden

\begin{tabular}{ccc}
\hline Semester & Jumlah & $\boldsymbol{\%}$ \\
\hline 2 & 61 & 26.1 \\
4 & 80 & 34.2 \\
6 & 93 & 39.7 \\
\hline Total & $\mathbf{2 3 4}$ & $\mathbf{1 0 0 \%}$ \\
\hline
\end{tabular}

Dari hasil penelitian maka diperoleh informasi tentang tingkatan semester responden di Universitas Bhakti Kencana Garut dengan 61 orang dari 234 responden adalah semester 2 atau sebanyak 26,1\% serta 80 orang atau $34,2 \%$ semester 4 dan 93 orang semester 6 atau sebanyak $39,7 \%$.

Tabel 2

\section{Jenis Kelamin Responden}

\begin{tabular}{ccc}
\hline $\begin{array}{c}\text { Jenis } \\
\text { Kelamin }\end{array}$ & Jumlah & \% \\
\hline Laki-laki & 55 & 23.5 \\
\hline
\end{tabular}

\begin{tabular}{ccc}
\hline Perempuan & 179 & 76.5 \\
\hline Total & $\mathbf{2 3 4}$ & $\mathbf{1 0 0 \%}$ \\
\hline
\end{tabular}

Dari hasil penelitian maka diperoleh informasi tentang tingkatan Jenis Kelamin Responden di Universitas Bhakti Kencana Garut dengan 55 orang dari 234 responden adalah laki-laki atau 23,5\% serta 179 orang atau 76,5\% adalah berjenis kelamin perempuan.

\section{Tabel 3}

\section{Jenis Sumber Informasi Tentang} Covid 19 Pada Responden

\begin{tabular}{lcc}
\hline \multicolumn{1}{c}{ Sumber } & Jumlah & \% \\
\hline Himbaua & 61 & 26.1 \\
pemerintah, & & 34.2 \\
Media Massa & 80 & 39.7 \\
Materi kuliah & 93 & $\mathbf{1 0 0 \%}$ \\
\hline \multicolumn{1}{c}{ Total } & $\mathbf{2 3 4}$ & $\mathbf{1 0 0}$ \\
\hline
\end{tabular}

Dari hasil penelitian maka diperoleh informasi tentang Sumber Informasi Tentang Covid 19 Pada Responden di Universitas Bhakti Kencana Garut paling banyak adalah dari media massa yaitu sebanyak $60,3 \%$ atau sebanyak 141 orang dari 234 orang responden.

\section{Tabel 4}

\begin{tabular}{ccc}
\multicolumn{3}{c}{ Sebaran Usia Responden } \\
\hline $\begin{array}{c}\text { Usia } \\
\text { (Tahun) }\end{array}$ & Jumlah & $\%$ \\
\hline $18-25$ & 233 & 99.5 \\
31 & 1 & 0.5 \\
\hline Total & $\mathbf{2 3 4}$ & $\mathbf{1 0 0 \%}$ \\
\hline
\end{tabular}

Dari hasil penelitian maka diperoleh informasi tentang Sebaran Usia Responden di Universitas Bhakti Kencana Garut paling banyak adalah usia diantara 18 sampai 25 tahun dan 
terdapat satu mahasiswa yang berusia 31 tahun.

\section{Tabel 5}

Sebaran Komorbid dari Responden

\begin{tabular}{lcc}
\hline Komorbid & Jumlah & \% \\
\hline Astma & 2 & 1 \\
Diabet & 2 & 1 \\
Gastritis & 4 & 2 \\
Hipetensi & 6 & 2.5 \\
Hypertiroid & 1 & 0,5 \\
Autoimun & 3 & 1.5 \\
Jantung & 2 & 1 \\
TBC & 1 & 0,5 \\
Tidak ada & 213 & 91 \\
\hline \multicolumn{1}{c}{ Total } & $\mathbf{2 3 4}$ & $\mathbf{1 0 0 \%}$ \\
\hline
\end{tabular}

Dari hasil penelitian maka diperoleh informasi tentang Komorbid dari Responden di Universitas Bhakti Kencana Garut. Untuk yang mengidap komorbid paling banyak adalah hipertensi yaitu 6 orang, sedangkan yang 1 mengaku tidak mempunyai komorbid sebanyak 213 orang.

\section{Variabel Univariat}

\section{Pengetahuan Responden}

Setelah dilakukan penelitian maka diperoleh hasil dari pengukuran pengetahuan responden di Universitas Bhakti Kencana Garut sebagai berikut:

\section{Tabel 6}

\section{Pengetahuan Responden}

\begin{tabular}{lcc}
\hline Pengetahuan & Jumlah & \% \\
\hline Kurang baik & 14 & 6 \\
Baik & 220 & 94 \\
\hline Jumlah & $\mathbf{2 3 4}$ & $\mathbf{1 0 0 \%}$ \\
\hline
\end{tabular}

Dari data di atas dapat diperoleh informasi bahwa paling banyak pengetahuan responden tentang covid-19 adalah sebanyak 220 responden berpengetahuan baik atau 94\% dari jumlah total 234 orang respomden yang diteliti.

\section{Tabel 7}

Sikap Responden

\begin{tabular}{ccc}
\hline \multicolumn{1}{c}{ Sikap } & Jumlah & \% \\
\hline Negatip & 130 & 55.6 \\
Positip & 104 & 44.4 \\
\hline Jumlah & $\mathbf{2 3 4}$ & $\mathbf{1 0 0 \%}$ \\
\hline
\end{tabular}

Dari data diatas dapat diperoleh informasi bahwa sikap responden tentang covid-19 adalah mayoritas sebanyak 130 responden bersikap negatif atau $55,6 \%$ dari jumlah total 234 orang respomden yang diteliti.

\section{Tabel 8}

Perilaku Responden

\begin{tabular}{ccc}
\hline Perilaku & Jumlah & \% \\
\hline Tidak Promosi & 83 & 35.5 \\
Promosi & 151 & 64.5 \\
\hline Total & $\mathbf{2 3 4}$ & $\mathbf{1 0 0 \%}$ \\
\hline
\end{tabular}

Dari data diatas dapat diperoleh informasi bahwa paling banyak responden tentang perilaku promosi kesehatan tentang covid-19 adalah mayoritas sebanyak 151 responden melaksanakan promosi kesehatan atau $64,5 \%$ dan sisanya sebanyak 83 orang atau $35,5 \%$ masih tidak melaksanakan promosi kesehatan.

\section{Variabel Bivariat}

Setelah dilakukan penelitian maka diperoleh hasil dari pengukuran bivariat responden di Universitas Bhakti Kencana Garut sebagai berikut: 


\section{Tabel 9}

Perilaku Responden

\begin{tabular}{|c|c|c|c|c|c|c|c|c|c|}
\hline \multirow[t]{3}{*}{ Variabel } & & \multicolumn{4}{|c|}{ Promosi Kesehatan } & \multicolumn{2}{|c|}{ Total } & \multirow{3}{*}{$\begin{array}{l}\mathrm{OR} \\
\text { Value }\end{array}$} & \multirow[t]{3}{*}{$\bar{P}$} \\
\hline & & \multicolumn{2}{|c|}{ Promosi } & \multicolumn{2}{|c|}{ Tidak Promosi } & \multirow[b]{2}{*}{$\mathrm{N}$} & \multirow[b]{2}{*}{$\%$} & & \\
\hline & & & $\%$ & $\mathrm{~N}$ & $\%$ & & & & \\
\hline \multirow[t]{2}{*}{ Pengetahuan } & Baik & 144 & 61 & 76 & 32 & 220 & 100 & 1,895 & 0,241 \\
\hline & Kurang Baik & 7 & 3 & 7 & 3 & 14 & 100 & & \\
\hline \multirow[t]{2}{*}{ Sikap } & Positif & 65 & 28 & 39 & 17 & 104 & 100 & 0,853 & 0,562 \\
\hline & Negatif & 86 & 37 & 44 & 18 & 130 & 100 & & \\
\hline
\end{tabular}

Berdasarkan tabel diatas. responden dengan pengetahuan yang baik dan melaksanakan promosi kesehatan adalah sebanyak 144 orang $(61 \%)$, pengetahuan yang baik dan tidak melaksanakan promosi kesehatan yaitu sebanyak 76 orang (32\%), pengetahuan yang Kurang baik dan melaksanakan promosi kesehatan sebanyak 7 orang (3\%), pengetahuan yang Kurang baik dan tidak melaksanakan promosi kesehatan sebanyak 7 orang (3\%), sedangkan responden dengan sikap yang positif dan melaksanakan promosi kesehatan adalah sebanyak 144 orang (61\%), Sikap yang positif dan tidak melaksanakan promosi kesehatan yaitu sebanyak 39 orang (17\%), Sikap yang negative dan melaksanakan promosi kesehatan sebanyak 86 orang (37\%), Sikap yang negative dan tidak melaksanakan promosi kesehatan sebanyak 44 orang $(18 \%)$.

$$
\text { Hasil uji korelasi }
$$
menggunakan uji bivariate antara pengetahuan dengan promosi kesehatan didapat $\mathrm{p}=0,241$ (nilai $\mathrm{p}<0,05)$, hal ini menunjukkan bahwa tidak terdapat hubungan yang signifikan antara pengetahuan dengan promosi kesehatan COVID-19, dan uji bivariate antara sikap dengan promosi kesehatan didapat $\mathrm{p}=0,562$ (nilai $\mathrm{p}<0,05$ ), hal ini menunjukkan bahwa tidak terdapat hubungan yang signifikan antara sikap dengan promosi kesehatan COVID-19 pada mahasiswa di Universitas Bhakti Kencana Garut.

\section{PEMBAHASAN}

\section{Pengetahuan Responden}

Berdasarkan tabel usia diatas dapat diketahui bahwa dari 234 responden sebagian besar dibawah 30 tahun, sedangkan sebagian besar jenis kelamin perempuan yaitu sebanyak 179 orang $(76,5 \%)$ dan sebagian kecil berjenis kelamn laki-laki sebanyak 55 orang $(23,5 \%)$. Selanjutnya untuk kriteria sumber informasi tentang covid 19 adalah dari media massa yaitu 141 orang atau $60.3 \%$ ) sedangkan paling sedikit aDalah dari sumber formal (Materi kuliah, jurnal dan seminar) yaitu 20 orang $(8,5 \%)$ dari total 234 orang responden, dari data tentang komorbid dapat kita peroleh informasi yaitu mayoritas responden mengakui tidak memiliki komorbid yatiu 213 orang (91\%).

$$
\text { Banyak faktor yang }
$$
mempengaruhi pengetahuan responden tentang pencegahan COVID-19. Menurut Notoatmodjo (2012), faktor-faktor yang mempengaruhi pengetahuan yaitu pendidikan, umur, pekerjaan dan faktor eksternal lainnya. Umur mempengaruhi pengetahuan, menurut pendapat Budiman (2013) yang menyatakan bahwa usia mempengaruhi daya tangkap dan pola pikir seseorang. Dengan bertambahnya usia seseorang menyebabkan semakin berkembangnya daya tangkap dan pola pikirnya sehingga pengetahuan 
yang didapat semakin meningkat juga. Uusia produktif merupakan usia dewasa yang aktif dalam kegiatan sehingga mendukung dalam belajar dan mengingat informasi yang diperoleh, akan tetapi padaumur-umur tertentu atau menjelang usia lanjut kemampuan penerimaan atau mengingat suatu pengetahuan akan berkurang.

Selain dari pendidikan formal, dapat diperoleh melalui orang lain maupun media massa antara lain majalah, televisi, surat kabar, dan radio. Dan seseorang dengan pendidikan rendah bukan berarti mutlak memiliki pengetahuan yang rendah pula. Namun pendapat lain mengatakan bahwa dengan pendidikan yang semakin tinggi maka seseorang akan semakin mudah menerima informasi sehingga semakin meningkat pula pengetahuan yang dimilikinya (Carter, 2011). Menurut pendapat peneliti, hasil penelitian ini sesuai dengan pendapat Notoatmodjo (2012) dimana pengetahuan bisa didapat selain melalui pendidikan formal dalam sekolah namun juga bisa diperoleh dari pendidikan nonformal di luar sekolah dan melalui pengalaman. Walaupun responden berada pada mayoritas berpendidikan rendah maka bukan berarti mutlak berpengetahuan rendah pula. Pendidikan tidak mempengaruhi pengetahuannya sebab responden dengan pengetahuan baik dapat memperoleh informasi dari pengalaman atau orang lain maupun media masa (Sumartini, 2020).

Menurut Notoatmodjo (2012) pendidikan seseorang mengenai kesehatan akan berpengaruh terhadap perilaku kesehatan, hal ini dikarenakan dengan pendidikan yang didapat akan memperoleh pengetahuan dan akan tercipta upaya pencegahan suatu penyakit. Semakin tinggi tingkat pendidikan seseorang akan memudahkannya menyerap ilmu pengetahuan, dengan demikian maka wawasannya akan lebih luas. Oleh karena itu, pengetahuan masyarakat tentang COVID-19 merupakan aspek yang sangat penting dalam masa pandemik seperti sekarang ini. Masyarakat perlu mengetahui penyebab COVID-19, karakteristik virusnya, tanda dan gejala, istilah yang terkait dengan COVID-19, pemeriksaan yang diperlukan dan proses transmisi serta upaya pencegahan penyakit tersebut (Purnamasari, 2020). Seseorang yang mempunyai pengetahuan yang baik terkait perilaku sehat maka ada kecenderungan untuk berperilaku yang baik pula (Gladys. 2016). Hal ini berarti bahwa untuk meningkatkan perilaku sehat dan selamat, maka perlu juga meningkatkan pengetahuan mengenai kesehatan.

\section{Sikap Responden}

Dari data diatas dapat diperoleh informasi bahwa sikap responden tentang covid-19 adalah mayoritas sebanyak 130 responden bersikap negatif atau 55,6\% dari jumlah total 234 orang respomden yang diteliti. Suparmi dan Cahyono (2015) menjelaskan sikap yang negatif tidak selalu mencerminkan pengetahuan yang rendah, juga sebaliknya pengetahuan yang tinggi atau baik tidak selalu mencerminkan 
sikap yang positif. WHO menyebutkan bahwa selain pengetahuan, dukungan sosial masyarakat memegang peranan penting dalam upaya meningkatkan sikap, kesadaran serta kesehatan mental masyarakat selama pandemic Covid-19 (WHO,2020).

\section{Perilaku Promosi COVID-19 oleh mahasiswa}

Perilaku yang baik dapat menjadi upaya pencegahan terhadap penularan COVID-19 (Audria, 2019). Perilaku kesehatan dipengaruhi oleh banyak faktor, diantaranya pengetahuan, persepsi, emosi, motivasi, dan lingkungan (Rahayu, 2014). Eksplorasi tentang perilaku kesehatan masyarakat dapat dilihat dari berbagai komponen, diantaranya persepsi tentang kerentanan penyakit, persepsi hambatan dalam upaya pencegahan, persepsi tentang manfaat, adanya dorongan, dan persepsi individu tentang kemampuan yang dimiliki untuk melakukan upaya pencegahan (Almi, 2020).

Penelitian ini menunjukkan bahwa perilaku promosi yang dilakukan responden sebagian besar pada kategori melaksanakan promosi kesehatan (64,5\%). Bentuk perilaku yang ditunjukkan antara lain kepatuhan dalam mempromosikan menjaga jarak saat di luar rumah, selalu mencuci tangan dengan sabun atau hand sanitizer sebelum masuk rumah, toko/minimarket, atm dan fasilitas lainnya, taat menggunakan masker saat berpergian dan tidak bersentuhan atau salaman dengan oranglain. Seseorang yang telah mengetahui tentang suatu informasi tertentu, maka dia akan mampu menentukan dan mengambil keputusan bagaiman dia harus menghadapinya. Dengan kata lain, saat seseorang mempunyai informasi tentang COVID-19, maka ia akan mampu untuk menentukan bagaimana dirinya harus berperilaku terhadap COVID-19 tersebut (Ahmadi, 2013).

Penelitian ini sejalan dengan yang dilakukan oleh (Purnamasari, 2020) menunjukkan bahwa sebanyak 95,8\% masyarakat Wonosobo mempunyai perilaku yang baik, bentuk perilaku yang ditunjukkan antara lain kepatuhan dalam menggunakan masker saat berada di luar rumah, mencuci tangan dengan sabun atau hand sanitizer secara sering, menghindari kerumunan dan menjaga social ataupun physical distancing. Cuci tangan adalah salah satu cara yang efektif untuk membunuh kuman, diketahui virus COVID-19 dapat menempel pada bagian tubuh terutama tangan yang menyentuh benda yang sudah tertular oleh droplet. Disampaikan oleh Kementerian Kesehatan bahwa 75\% penularan virus covid adalah melalui percikan air ludah pada benda (Kemenkes, 2020). Oleh karena itu dalam penelitian ini, sebagaian responden melakukan cuci tangan setelah memegang benda yang telah disentuh sesuai dengan protokol kesehatan.

\section{Hubungan Pengetahuan, sikap dengan Perilaku Promosi Kesehatan Tentang COVID-19}

Berdasarkan tabel 9 diatas. responden dengan pengetahuan yang baik dan melaksanakan promosi 
kesehatan adalah sebanyak 144 orang $(61 \%)$, pengetahuan yang baik dan tidak melaksanakan promosi kesehatan yaitu sebanyak 76 orang (32\%), pengetahuan yang Kurang baik dan melaksanakan promosi kesehatan sebanyak 7 orang (3\%), pengetahuan yang Kurang baik dan tidak melaksanakan promosi kesehatan sebanyak 7 orang (3\%), sedangkan responden dengan sikap yang positif dan melaksanakan promosi kesehatan adalah sebanyak 144 orang $(61 \%)$, Sikap yang positif dan tidak melaksanakan promosi kesehatan yaitu sebanyak 39 orang (17\%), Sikap yang negative dan melaksanakan promosi kesehatan sebanyak 86 orang (37\%), Sikap yang negative dan tidak melaksanakan promosi kesehatan sebanyak 44 orang (18\%).

Hasil uji korelasi menggunakan uji bivariate antara pengetahuan dengan promosi kesehatan didapat $\mathrm{p}=0,241$ (nilai $\mathrm{p}<0,05)$, hal ini menunjukkan bahwa tidak terdapat hubungan yang signifikan antara pengetahuan dengan promosi kesehatan COVID-19, dan uji bivariate antara sikap dengan promosi kesehatan didapat $\mathrm{p}=0,562$ (nilai $\mathrm{p}<0,05$ ), hal ini menunjukkan bahwa tidak terdapat hubungan yang signifikan antara sikap dengan promosi kesehatan COVID-19 pada mahasiswa di Universitas Bhakti Kencana Garut.

Pengetahuan merupakan elemen yang sangat penting dalam membentuk keyakinan serta sikap yang positf (Tarallo dan Neri,2017). Minimnya pengetahuan tentang
Covid-19 menjadi salah satu faktor mediasi peningkatan kasus penyakit yang disebabkan oleh virus. Pemahaman yang buruk tentang penyakit dan proses penularan penyakit dapat berkontribusi dalam peningkatan angka kasus penyakit tersebut (Ilesanmi dan Alele, 2016). Namun demikian hasil penelitian menunjukkan bahwa tidak ada hubungan antara pengetahuan, sikap responden terhadap perilaku promosi kesehatann pada mahasiswa. Hasil ini sejalan dengan hasil penelitian (Dewi, Putere dan Masyeni. 2020), dimana tidak ditemukan adanya hubungan yang signifikan antara pengetahuan, sikap responden terhadap perilaku promosi kesehatan.

Penelitian ini sejalan yang dilakukan oleh (Purnamasari, 2020) menunjukkan hasil pengetahuan masyarakat Kabupaten Wonosobo tentang Covid 19 berada pada kategori Baik (90\%) dan hanya 10\% berada pada kategori cukup. Untuk perilaku masyarakat Kabupaten Wonosobo terkait Covid 19 seperti menggunakan masker, kebiasaan cuci tangan dan physical / social distancing menunjukkan perilaku yang baik sebanyak $95,8 \%$ dan hanya 4,2\% masyarakat berperilaku cukup baik.Terdapat hubungan bermakna antara pengetahuan dengan perilaku masyarakat tentang Covid 19 dengan p-value 0,047 .

2010) Menurut (Wawan dan Dewi, pengetahuan merupakan hasil "tahu" dan ini terjadi setelah orang mengadakan penginderaan terhadap suatu objek tertentu. Pengetahuan 
tentang berbagai cara dalam mencapai pemeliharaan kesehatan, cara menghindari penyakit, maka akan meningkatkan pengetahuan masyarakat (Priyanto, 2018). Pengetahuan memegang peranan penting dalam penentuan perilaku yang utuh karena pengetahuan akan membentuk kepercayaan yang selanjutnya dalam mempersepsikan kenyataan, memberikan dasar bagi pengambilan keputusan dan menentukan perilaku terhadap objek tertentu (Novita dkk, 2014) sehingga akan mempengaruhi seseorang dalam berperilaku.

Peneliti berasumsi bahwa pengetahuan sangat menentukan setiap individu sehingga akan mempengaruhi perilaku dalam kehidupan sehari-hari. Karena semakin tinggi tingkat pengetahuan seseorang maka semakin mudah untuk menentukan apa yang harus ia pilih dan apa yang ia harus lakukan dalam kehidupannya. Sejalan dengan yang dikatakan oleh (Prihantana, 2016) bahwa pengetahuan memiliki kaitan yang erat dengan keputusan yang akan diambilnya, karena dengan pengetahuan seseorang memiliki landasan untuk menentukan pilihan. Selain itu, tingkat pengetahuan yang tinggi ini juga didukung dengan tingkat pendidikan,tingkat pendidikan seseorang yang tinggi akan semkin mudah untuk mendapatkan akses informasi tentang suatu permasalahan (Yanti B dkk, 2020) Penelitian lain yang sejalan dengan hasil penelitian ini adalah penelitian yang dilakukan oleh Clements JM (2020) yang menunjukan bahwa masyarakat
Amerika Serikat memiliki pengetahuan dan perilaku yang baik dan Zhonng BL (2020) yang meneliti pada masyarakat China sebagai tempat awal ditemukannya Virus corona ini juga memiliki pengetahuan dan perilaku yang baik dan positif. Hal ini juga dihubungkan dengan pengalaman masyarakat China menghadapi wabah SARS pada Tahun 2000-an.

\section{SIMPULAN}

Hasil uji statistik diperoleh $\mathrm{p}=0,241$ dalam hal ini $\mathrm{p}<0,05$ maka dapat disimpulkan tidak ada hubungan antara pengetahuan dengan perilaku promosi kesehatan.

Hasil uji statistik diperoleh $\mathrm{p}$ $=0,562$ dalam hal ini $\mathrm{p}<0,05$ maka dapat disimpulkan tidak ada hubungan antara sikap dengan perilaku promosi kesehatan.

\section{SARAN}

Untuk Mahasiswa disarankan lebih giat membantu program pemerintah khususnya melakukan promosi kesehatan pada saat pandemi covid 19.

\section{UCAPAN TERIMA KASIH}

Peneliti mengucapkan terimakasih kepada semua pihak yang sudah mendukung terlaksananya penelitian ini terutama keluarga, rekan rekan serta Universitas Bhakti Kencana yang telah mendanai penelitian ini sehingga dapat diselesaikan sesuai dengan rencana.

\section{DAFTAR PUSTAKA}

Ahmadi. (2013).

Kesehatan 
Masyarakat Teori dan Aplikasi. Jakarta: Raja Grafindo.

Almi. (2020).Analisis Penyebab Masyarakat Tidak Patuh pada Protokol COVID-19. https://almi.or.id/2020/06/05/ana lisis-penyebab-masyarakattidak-patuh-pada-protokolCOVID-19/.

Audria O. AWD. (2019). Hubungan Pengetahuan dan Sikap Terhadap Perilaku Cuci Tangan pada Masyarakat Kelurahan Pegirian. Jurnal Promkes: The Indonesia Journal of Health Promotion and Health Education. No.1. Vol.1.

Budiman, A. (2013). Kapita Selekta Kuesioner : Pengetahuan dan Sikap dalam Penelitian Kesehatan. Jakarta : Salemba Medika.

Carter, William K. (2011). Akuntasi biaya. Penerjemah: Krista, Buku 1, Edisi Ketiga, Salemba Empat, Jakarta.

Clements J.M. (2020). Knowledge and Behaviors Toward COVID19 Among US Residents During the Early Days of the Pandemic: Cross-sectional Online Questionnaire. JMR public health and surveillance. 6(2) e19161.

https://doi/org/10.2196/19161.

Dewi, P., Putere, S., dan Masyeni, S.(2020). The relationship between the level of knowledge, attitudes and behaviour in patients with sexually transmitted diseases at Puskesmas Abang I Karangasem. European Union
Digital Library.

Gladys A. 2016. Hubungan Antara Usia, Jenis Kelamin, Lama Kerja, Pengetahuan, Sikap Dan Ketersediaan Alat Pelindung Diri (APD) Dengan Perilaku Penggunaan APD Pada Tenaga Kesehatan. Jurnal Publikasi Kesehatan Masyarakat Indonesia. Vol.3 (3).

Ilesanmi, O dan Alele, F. (2016). Knowledge, Attitude and Perception of Ebola Virus Disease among Secondary School Students in Ondo State, Nigeria, October, 2014. PLOS Currents Outbreaks. 1.

Kemenkes, RI. (2020). Pedoman Pencegahan dan Pengendalian Coronavirus Disease (COVID19). Germas, 0-115.

Mona, N. (2020). Konsep Isolasi Dalam Jaringan Sosial Untuk Meminimalisasi Efek Contagious (Kasus Penyebaran Virus Corona Di Indonesia). Jurnal Sosial Humaniora Terapan, 2(2).

Morfi, C. W. (2020). Kajian terkini Coronavirus disease 2019 (COVID-19). Jurnal Ilmu Kesehatan Indonesia, 1(1).

Notoatmodjo S. (2010). Konsep Perilaku Kesehatan. Dalam: Promosi Kesehatan Teori \& Aplikasi edisi revisi. Jakarta: Rineka Cipta.

Notoatmodjo S. (2010). Pendidikan dan Perilaku Kesehatan. Jakarta: Rineka Cipta;.

Novita, dkk. (2014). Tingkat Pengetahuan Tentang TB Paru Mempengaruhi Penggunaan 
Masker Di Ruang Paru Rumkital Dr. Ramelan Surabaya. Jurnal Ilmiah Kesehatan. Vol. 7 No.12. Surabaya : STIKES Hang Tuah.

Prihantana, dkk. (2016). Hubungan Pengetahuan Dengan Tingkat Kepatuhan Pengobatan Pada Pasien Tuberkolosis Di RSUD Dr. Soehadi Prijonegoro Sragen. Jurnal Farmasi Sains Dan Praktis. Vo. 2. No. 1. Poltekkes Bhakti Mulia.

Priyanto, Agus. (2018). Hubungan Tingkat Pengetahuan Dengan Perilaku Pencegahan Kekambuhan Luka Diabetik. Jurnal Ners Dan Kebidanan. Vol. 5 No. 3. Kediri : STIKES Ganesha Husada.

Prof.Dr.Soekidjo Notoatmodjo. (2012). Metodologi Penelitian Kesehatan, Rineka Cipta.Jakarta

Purnamasari, I. Anisa E.R. (2020). Tingkat pengetahuan dan perilaku masyarakat Kabupaten Wonosobo tentang COVID-19. Jurnal ilmiah kesehatan. Diakses tanggal : 10 agustus 2020.

Rahayu, W. et al., (2014), Analisis Pengaruh Injeksi Mikroorganisme Potensial pada Parameter Kompresibilitas Tanah Gambut Kayu Agung Sumatera Selatan, Proceeding of 18th Annual National Conference on Geotechnical Engineering: 97-103, Indonesia: Jakarta.

Sumartini. N. P. Dewi P. Ni Ketut. S. (2020). Pengetahuan Pasien yang Menggunakan Terapi Komplementer Obat Tradisional tentang Perawatan Hipertensi di
Puskesmas Pejeruk Tahun 2019. Bima Nursing Journal. No.1 Vol.1. e-ISSN: 2715-6834.

Suparmi, Desianti,O.,\& Cahyono,B. (2015). The Correlation Between Knowledge and Attitude on Food Colorant Uses of PKK Mothers in Penggaron Lor Village. Procedia Food Science. 3. 156-161.

Tarallo, R. S., \& Neri, A. L. (2017).. Attitudes of Elderly Persons and Professionals towards Intergenerational Exchanges. Revista Brasileira de Geriatria e Gerontologia. 20(3), 421-429.20

Wawan, A dan Dewi. M (2010). Teori dan Pengukuran Pengetahuan, Sikap, Dan Perilaku Manusia. Yogyakarta: Nuha Medika.

World Health Organization. (2020). Weekly Operational Update on COVID-19. Retrieved from https://www.who.int/healthtopics/coronavirus.

Yanti, B., Wahyudi, E., Wahiduddin,W., Novika, R. G. H., Arina, Y.M. D., Martani, N.S., \& Nawan, N. (2020). Community

Knowledge,Attitudes, and

Behavior Towards Social Distancing Policy As Prevention Transmission of Covid-19 in Indonesia. Jurnal Administrasi Kesehatan Indonesia, https://doi.org/10.20473/jaki.v8i.

Zhang, M., Zhou, M., Tang, F.,Wang, Y., Nie, H., Zhang, L., \& You, G. (2020). Knowledge,attitude, and practice regarding COVID-19 
Jurnal Mitra Kencana Keperawatan dan Kebidanan Volume 5 Nomor 2, November 2021, Hal. 32 - 44 $P-I S S N$ : 2599-0055, E-ISSN : 2615-1987

DOI 10.54440

among healthcare workers in

Henan,China.Journal of

Hospital Infection, 183187.

https://doi.org/10.1016/j.jhin.

2020.04.012. 